Article

\title{
Protective Effect of Chemically Characterized Polyphenol-Rich Fraction from Apteranthes europaea (Guss.) Murb. subsp. maroccana (Hook.f.) Plowes on Carbon Tetrachloride-Induced Liver Injury in Mice
}

\author{
Fatima Ez-Zahra Amrati ${ }^{1}$, Mohammed Bourhia ${ }^{2, *(D)}$, Meryem Slighoua ${ }^{1}$, Smahane Boukhira ${ }^{1}$, Riaz Ullah ${ }^{3}$ (D), \\ Essam Ezzeldin ${ }^{4}$, Gamal A. E. Mostafa ${ }^{4,5}{ }^{\mathbb{D}}$, Andriy Grafov ${ }^{6}{ }^{\mathbb{D}}$ and Dalila Bousta ${ }^{1}$
}

check for updates

Citation: Amrati, F.E.-Z.; Bourhia, M.; Slighoua, M.; Boukhira, S.; Ullah, R.; Ezzeldin, E.; Mostafa, G.A.E.; Grafov, A.; Bousta, D. Protective Effect of Chemically Characterized Polyphenol-Rich Fraction from Apteranthes europaea (Guss.) Murb. subsp. maroccana (Hook.f.) Plowes on Carbon Tetrachloride-Induced Liver Injury in Mice. Appl. Sci. 2021 11, 554. https://doi.org/10.3390/ app11020554

Received: 6 December 2020 Accepted: 6 January 2021 Published: 8 January 2021

Publisher's Note: MDPI stays neutral with regard to jurisdictional clai$\mathrm{ms}$ in published maps and institutional affiliations.

Copyright: (C) 2021 by the authors. Licensee MDPI, Basel, Switzerland. This article is an open access article distributed under the terms and conditions of the Creative Commons Attribution (CC BY) license (https:// creativecommons.org/licenses/by/ $4.0 /)$
1 Laboratory of Biotechnology, Health, Agrofood and Environment (LBEAS), Faculty of Sciences Dhar El Mehraz, Sidi Mohamed Ben Abdellah University, Fez 30000, Morocco; fatima.ezzahra.amrati@gmail.com (F.E.-Z.A.); slighoua.meryem@gmail.com (M.S.); smahaneboukhira@gmail.com (S.B.); boustadalila@gmail.com (D.B.)

2 Laboratory of Chemistry-Biochemistry, Environment, Nutrition, and Health, Faculty of Medicine and Pharmacy, University of Casablanca, B.P 5696, Casablanca 20250, Morocco

3 Department of Pharmacognosy, College of Pharmacy, King Saud University, Riyadh 11451, Saudi Arabia; rullah@ksu.edu.sa

4 Department of Pharmaceutical Chemistry, College of Pharmacy, King Saud University, Riyadh 11451, Saudi Arabia; esali@ksu.edu.sa (E.E.); gmostafa@ksu.edu.sa (G.A.E.M.)

5 Micro-Analytical Laboratory, Applied Organic Chemistry Department, National Research Center, Dokki, Cairo 12622, Egypt

6 Laboratory of Inorganic Chemistry, Department of Chemistry, Faculty of Sciences, 00100 Helsinki, Finland; andriy.grafov@helsinki.fi

* Correspondence: bourhiamohammed@gmail.com

\begin{abstract}
Apteranthes europaea (Guss.) Murb. subsp. maroccana (Hook.f.) Plowes (A. europaea) is a medicinal plant widely used in traditional medicines to treat various diseases including hepatic pathogenesis. This study was conducted to evaluate the protective effect of chemically characterized polyphenol-rich fraction from $A$. europaea on carbon tetrachloride-induced liver injury in mice. The chemical characterization of A. europaea polyphenol-rich fraction was carried out using HPLC-DAD (high-performance liquid chromatography (HPLC) with a diode-array detector (DAD)). Carbon tetrachloride (CCl4) was used to induce liver injuries in mice as described in previous works. A polyphenol-rich fraction from A. europaea was used at a dose of $50 \mathrm{mg} / \mathrm{Kg}$ to study its hepatoprotective effect. Next, histopathological and biochemical alterations were investigated. The HPLC analysis revealed the presence of several phenolic compounds: gallic acid, methyl gallate, rutin, ferulic acid, and resorcinol. Regarding the mice treated with a polyphenol-rich fraction from A. europaea up to $50 \mathrm{mg} / \mathrm{Kg}$ and carbon tetrachloride, no significant biochemical nor histological alterations occurred in their liver; meanwhile, serious biochemical and histopathological changes were noted for liver recovered from the mice treated with carbon tetrachloride only. In conclusion, A. europaea extract is a promising source of hepatoprotective agents against toxic liver injury.
\end{abstract}

Keywords: Apteranthes europaea (Guss.) Murb. subsp. maroccana (Hook.f.) Plowes; polyphenol-rich fraction; phytochemical analysis; carbon tetrachloride; chronic liver injury; histopathological examination

\section{Introduction}

The liver plays a crucial role in protecting the organism and maintaining the metabolic homeostasis of the body through the detoxification of toxic chemicals. It transforms lipophilic chemicals into hydrophilic metabolites rapidly eliminated from the body via urine [1,2]. This biotransformation may go along with the formation of reactive free radical 
metabolites with a capacity of binding to intracellular macromolecules which can lead to hepatic diseases [1].

Even though there has been enormous advances in modern medicines, the conventional drugs used for the treatment of liver disease are still not completely effective and may present diverse side effects [3]. Therefore, the development of alternative medicines for medication against liver diseases is becoming highly appreciated more than ever before.

Apteranthes europaea (Guss.) Murb. subsp. maroccana (Hook.f.) Plowes (A. europaea) is a succulent leafless species belonging to the family Apocynaceae, which grows in Jordan and the Mediterranean countries [4].

In traditional medicines, the aerial parts of A. europaea are recommended for use as a juice or as a powder mixed with honey or milk to fight diseases [5]. Some pharmacological activities of A. europaea including anti-inflammatory, anti-cyst, anticancer, anti-diabetic, anti-gastrointestinal disorders, anti-atherosclerosis, anti-hyperglycemia, anticancer, antimicrobial, antidiabetic, antioxidant, and cytotoxic have been investigated elsewhere [6-10].

Some chemical compounds contained in the studied plant have already been identified including luteolin, gallic acid, hesperetin, quercetin, myricetin, ferulic acid, salicylic acid, naringenin-7-glucoside, rutin, rosmarinic acid, ellagic acid, quercetin, and epicatechin $[8,11]$.

Due to its presumed therapeutic effects, this study was carried out to probe the potential protective effect of chemically characterized polyphenol-rich fraction from $\mathrm{A}$. europaea on carbon tetrachloride-induced liver injury in mice since no previous work has investigated this objective up to now.

\section{Materials and Methods}

\subsection{Solvents and Reagents}

Carbon tetrachloride (CCl4), olive oil, standard compounds: apigenin, daidzein, ferulic acid, rutin, kaempferol, luteolin, methyl gallate, quercetin, gallic acid and resorcinol, HPLC grade acetonitrile (ACN), methanol $(\mathrm{MeOH})$, and formic acid were purchased from Sigma Aldrich (Darmstadt, Germany). HPLC-grade water was prepared using a Millipore Milli-Q purification system (M SimPak 2 Catalogue No SIMPAK0D2, Code 0081).

\subsection{Plant Material}

Apteranthes europaea (Guss.) Murb. subsp. maroccana (Hook.f.) aerial parts were collected from the Imouzzer region in the Middle Atlas Mountains, Morocco. Authentication of the studied plant was made by the botanist Amina Bari and given the voucher number 18I4C001 before being deposited at the herbarium of the Department of Biology, Faculty of Sciences Dhar El Mahraz, Fez, Morocco [8]. The aerial part of A. europaea was dried in a shady place in a well-ventilated room before being ground into powder (Figure 1).

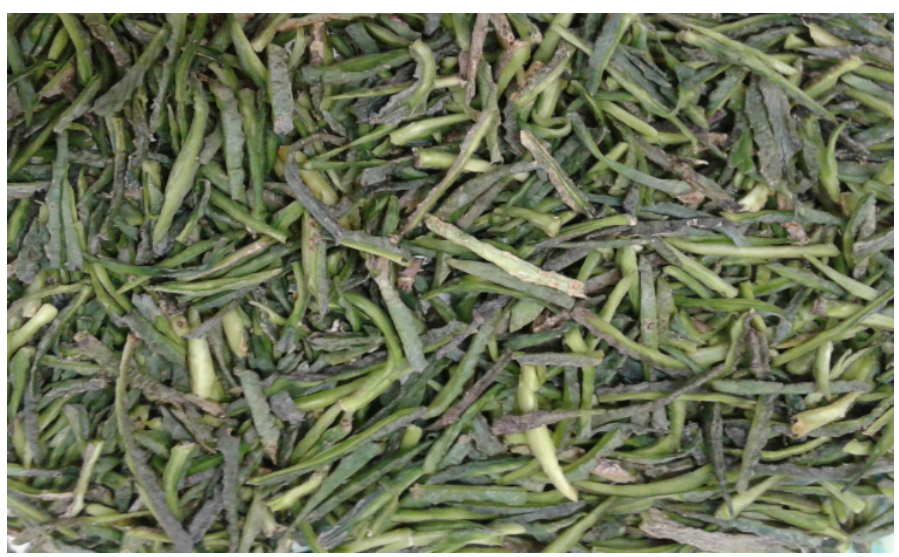

Figure 1. Aerial parts of A. europaea. 


\subsection{Preparation of Polyphenol-Rich Fraction}

Briefly, a total of $100 \mathrm{~g}$ of A. europaea powder (aerial parts) was extracted three times with $300 \mathrm{~mL}$ of methanol. Next, the mixture was concentrated under reduced pressure and low temperature using a rotary evaporator $\left(40^{\circ} \mathrm{C}\right)$. The dry extract obtained was dissolved in $500 \mathrm{~mL}$ of distilled water and then successively extracted three times again with $200 \mathrm{~mL}$ of hexane, chloroform, and ethyl acetate. Thereafter, the ethyl acetate layer was evaporated under reduced pressure using a rotary evaporator (Model BÜCHI 461). The residue obtained was dissolved again in $300 \mathrm{~mL}$ water and freeze-dried to obtain a polyphenol-rich fraction (Figure 2) [12]. The extraction yield obtained for polyphenols was $7 \%$.

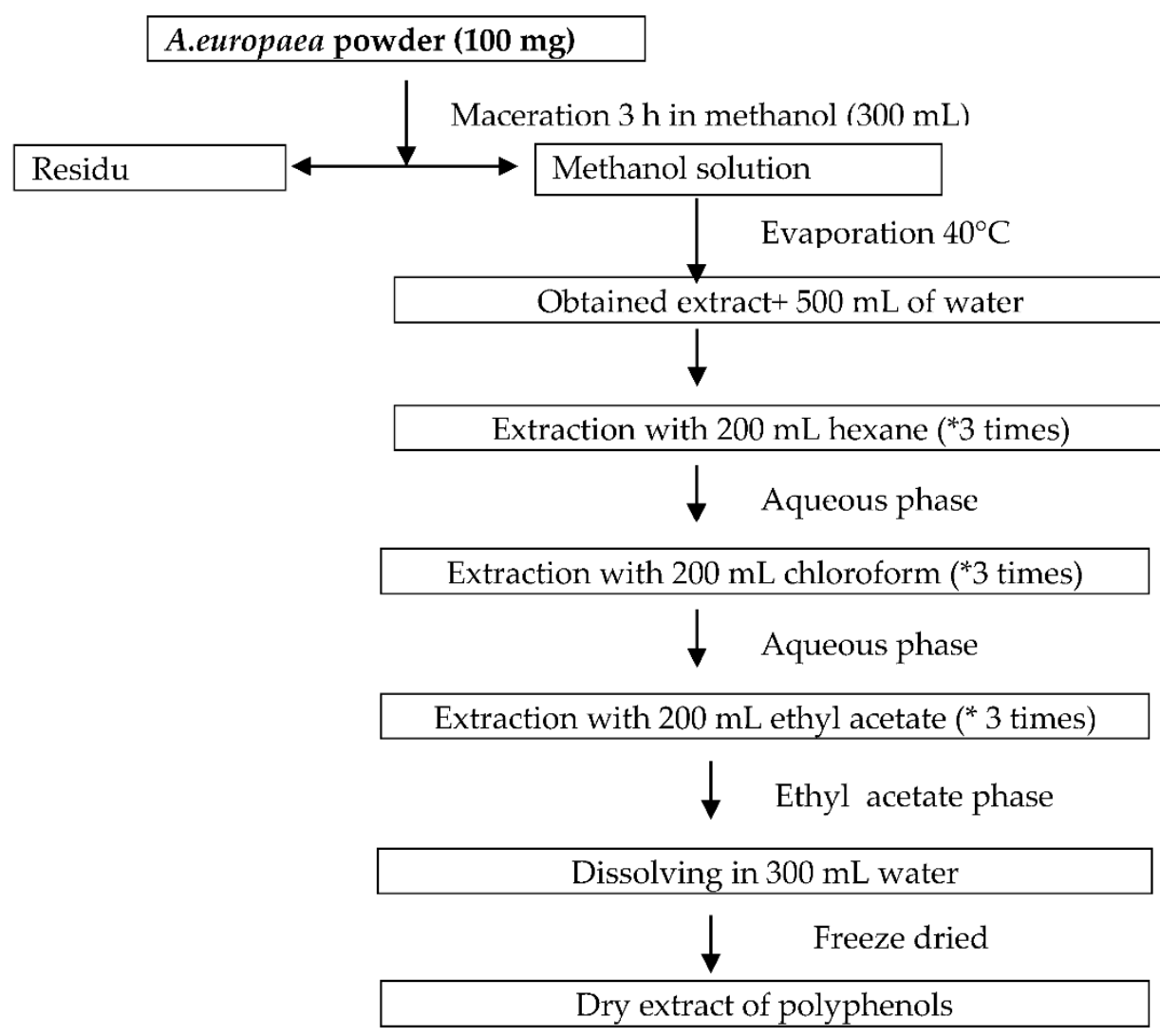

Figure 2. Schematic drawing of liquid-liquid extraction of polyphenol-rich fraction from A. europaea.

\subsection{Chemical Analysis of A. europaea Polyphenol-Rich Fraction}

HPLC-DAD Analysis

The phytochemical characterization of polyphenol-rich fraction extract from $\mathrm{A}$. europaea was carried out according to the HPLC method described by Seal (2016), with some modifications [13].

The high-performance liquid chromatography system (Agilent Technologies, 6120) (Helsinki, Finland) was equipped with a quaternary pump (G7111A) and coupled with a diode array detector (DAD). The peaks were detected using a DAD operating at $250 \mathrm{~nm}$. Compounds were identified by performing a comparison with standard spectra under the same conditions. Before being injected, polyphenol and standards samples were filtered through a $0.2 \mu \mathrm{m}$ membrane filter to remove particulate residues. Afterward, a volume of $5 \mu \mathrm{L}$ of polyphenol extract was injected over a C18 ZORBAX Eclipse Plus (PN: 95 99 93-902; SN: USU*B02265; LN: B09086) $4.6 \times 150 \mathrm{~mm}$ column) at a flow rate of $0.7 \mathrm{~mL} / \mathrm{min}$ with the column temperature set to $30^{\circ} \mathrm{C}$. The mobile phase was composed of acidified water (acetic acid $0.1 \%$ ) (A) and acetonitrile (B) with a total running time of $65 \mathrm{~min}$, as described 
by Seals [13]. The gradient elution conditions were maintained as follows: from 20 to $50 \%$ B for $28 \mathrm{~min}, 50$ to $70 \%$ B for $39 \mathrm{~min}, 70$ to $90 \%$ B for $50 \mathrm{~min}$, and 90 to $10 \%$ for $65 \mathrm{~min}$.

\subsection{Animal Material}

Adult male Swiss mice aged 2 months and weighing between 20 and $25 \mathrm{~g}$ were used to perform the current study. Animals were obtained from the animal house at the Department of Biology, Sidi Mohamed Ben Abdellah, Faculty of Sciences, Fez University. The animals were housed in controlled laboratory conditions with a set temperature $\left(23 \pm 2{ }^{\circ} \mathrm{C}\right)$ and light cycle (12 h light/dark cycles). The animals were allowed free access to food and water ad libitum. The Animal Ethics Review Committee at the faculty of Sciences, Fez, Morocco, approved this study under the ethical clearance number 04/2019/LBEAS. The use of laboratory animals in all experimental procedures was conducted according to ethical guidelines for the care and use of laboratory animals.

\subsection{Administration of Polyphenol-Rich Fraction}

A total of $50 \mathrm{mg} / \mathrm{Kg}$ of polyphenol-rich fraction from A. europaea was dissolved in $\mathrm{NaCl}$ solution before being administered to mice via oral gavage. Carbon tetrachloride was prepared in olive oil (vehicle) and given to mice intraperitoneally.

\subsection{Carbon Tetrachloride-Induced Liver Injury in Mice and Polyphenol Treatment}

Animals fasted overnight for $16 \mathrm{~h}$ before the administration of carbon tetrachloride. Afterward, they were divided into four equal experiment groups, with 10 in each group. Afterward, two groups were selected to be treated with $\mathrm{NaCl}$ (group 1) and A. europaea polyphenol extract only at the dose of $50 \mathrm{mg} / \mathrm{Kg}$ (group 2), and the third group (group 3) was given $40 \% \mathrm{CCl} 4$ / olive oil ( $1 \mathrm{~mL} / \mathrm{Kg}$ body weight twice per week) intraperitoneally (i.p) for 8 weeks to induce chronic liver injury (group 2). In addition to CCl4 administration, the experimental group (group 4) was simultaneously treated with the polyphenol-rich fraction from A. europaea at a dose of $50 \mathrm{mg} / \mathrm{Kg}$ (4 days per week with oral administration) for 8 weeks [14].

\subsection{Serum Biochemical Analysis}

At the end of the experimental period ( 8 weeks), the animals were anesthetized with sodium pentobarbital at a dose of $30 \mathrm{mg} / \mathrm{Kg}$ before being sacrificed for blood and organ collection. Blood samples were collected in heparin tubes $(0.2 \mathrm{~mL}$ with $10 \mathrm{U} / \mathrm{mL}$ heparin (Innohep)) and then centrifuged at $1500 \mathrm{rpm}$ for $10 \mathrm{~min}$. Next, the recovered plasma was analyzed for liver enzymes (aspartate aminotransferase (AST) and alanine aminotransferase (ALT)).

\subsection{Histopathological Examination}

Livers of mice were excised for histopathological examination. The tissues were washed and fixed in 10\% formalin solution, dehydrated with alcohol, and then enclosed in paraplast. Afterward, tissues were embedded in paraffin and sectioned. Sections of $5 \mu \mathrm{m}$ thickness were cut and mounted on slides. Next, sections were stained with hematoxylineosin before being read using a light microscope [15].

\subsection{Statistical Analysis}

The results obtained were expressed as mean \pm SEM (standard error of the mean). The data were statistically analyzed using GraphPad Prism, and one-way analysis of variance (ANOVA) was used to perform the comparison. A $p$-value $<0.05$ was considered significant. 


\section{Results}

\subsection{Phytochemical Composition of A. europaea}

HPLC-DAD Analysis

The HPLC analysis of polyphenol-rich fraction from A. europaea affirmed the presence of four potentially active compounds including gallic acid, methyl gallate, rutin, ferulic acid, and resorcinol (Figures 3 and 4). Ferulic acid was the major phenolic compound contained in the extract followed by gallic acid, methyl gallate, rutin, and resorcinol. The concentrations of the identified phenolic compounds in A. europaea are presented in Table 1.

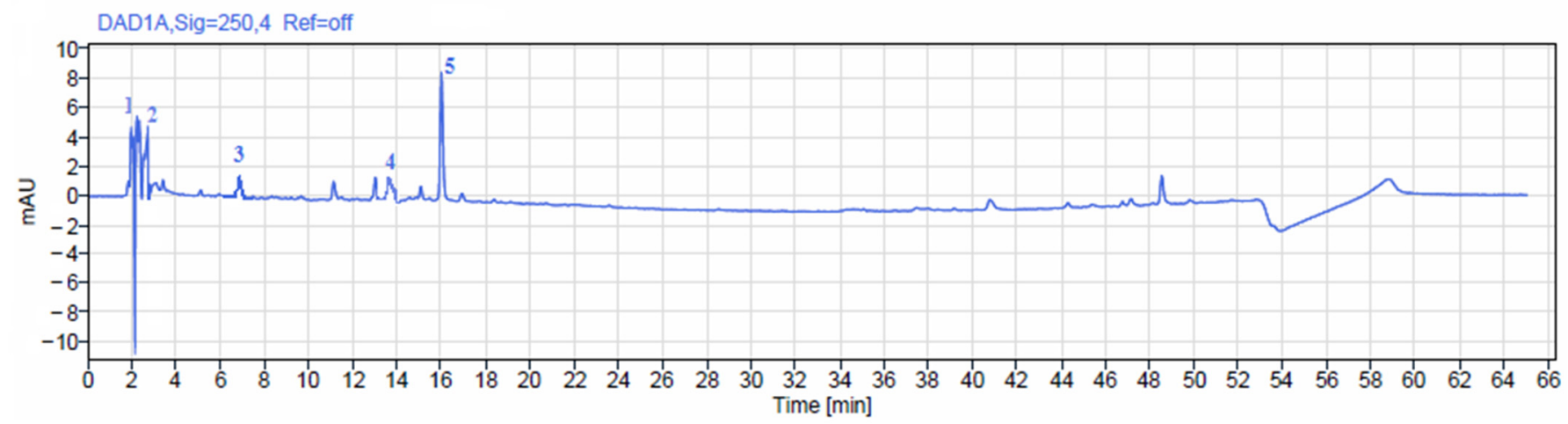

Figure 3. Chromatographic profile of phenolic compounds identified in polyphenol extract of A. europaea.<smiles>COc1cc(/C=C/C(=O)O)ccc1O</smiles>

Ferulic acid<smiles>C[C@@H]1OC(OC[C@H]2O[C@@H](Oc3c(-c4ccc(O)c(O)c4)oc4cc(O)cc(O)c4c3=O)[C@H](O)[C@H](O)[C@@H]2O)[C@H](O)[C@H](O)[C@@H]1O</smiles>

Rutin<smiles>COC(=O)c1cc(O)c(O)c(O)c1</smiles>

Methyl gallate

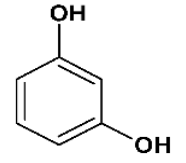

Resorcinol<smiles>O=C(O)c1cc(O)c(O)c(O)c1</smiles>

Gallic acid

Figure 4. Chemical structures of compounds identified using HPLC of the polyphenol-rich fraction of A. europaea. 
Table 1. Phenolic compounds identified using HPLC in a polyphenol extract of A. europaea.

\begin{tabular}{cccc}
\hline Peak & Phenolic Compound & RT std $(\mathbf{m i n})$ & Concentration $(\mu \mathrm{g} / \mathbf{m L})$ \\
\hline 1 & Gallic acid & 2 & 225.01 \\
2 & Methyl gallate & 2.89 & 187.10 \\
3 & Resorcinol & 6.89 & 69.9 \\
4 & Rutin & 13.49 & 77.59 \\
5 & Ferulic acid & 15.21 & 299.60 \\
\hline
\end{tabular}

\subsection{Serum Biochemical Analysis}

The results of transaminases (AST (U/L), ALT (U/L)) dosed in the serum recovered from the mice fed or not with A. europaea polyphenolic extract after carbon tetrachloride administration are presented in Table 2. The values of enzymatic activities of ALT and AST measured in the plasma recovered from the mice treated with carbon tetrachloride alone (group 3) were found to be significantly higher than those dosed in the serum of the mice treated with both carbon tetrachloride and polyphenol extract (poly A.E + CCl4) (group 4) $(p<0.05)$. Moreover, no significant difference was observed between the untreated mice $(\mathrm{NaCl})$ (group 1) and those treated with polyphenol-rich fraction only (group 2) nor the experimental group 4 concentering transaminases' activities $(p>0.05)$. The comparison of group 1 and group 3 showed a significant difference in transaminases' activities, which significantly increased in the serum of the latter $(p<0.05)$.

Table 2. Blood chemistry values of mice treated with $\mathrm{NaCl}$ (group 1), A. europaea polyphenols (poly A.E) (group 2), CCl4 alone (group 3), CCl4 combined of $50 \mathrm{mg} / \mathrm{kg}$ of the polyphenol-rich fraction (group 4).

\begin{tabular}{ccccc}
\hline Biochemical Parameters & \multicolumn{3}{c}{ Groups of Mice } \\
\hline & Group 1 (Nacl) & Group 2 (Poly A.E) & Group 3 (CCl4 Alone) & Group 4 (Poly A.E + CCl4) \\
\hline AST (U/L) & $307.7 \pm 30.37$ & $395.01 \pm 38.06$ & $748 \pm 58.89^{*}$ & $496.3 \pm 47.46$ \\
ALT (U/L) & $46.13 \pm 1.041$ & $47.13 \pm 1.9$ & $63.33 \pm 2.028^{*}$ & $41.33 \pm 2.906$ \\
\hline
\end{tabular}

Results are expressed as mean $\pm \mathrm{SD}$ (male $n=10) .{ }^{*}$ Significantly different, $p<0.05$.

\subsection{Macroscopic and Histopathological Alterations}

The histopathological examination of liver excised from the mice treated with poly $\mathrm{C} . \mathrm{E}+\mathrm{CCl} 4$ (group 4) showed normal parenchyma when compared to the mice treated with CCl4 alone (group 3), where we noted serious injuries including abdominal distension, hypertrophy, degeneration, cavitation, necrosis, and cysts of yellowish color. No histopathological injuries were detected in liver tissues of mice treated with polyphenol-rich fraction only (group 2) when compared to the untreated group (Figures 5 and 6). 


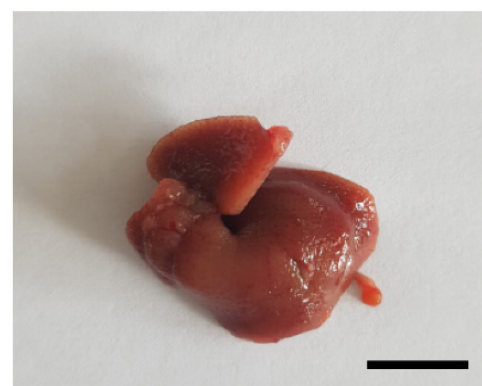

A

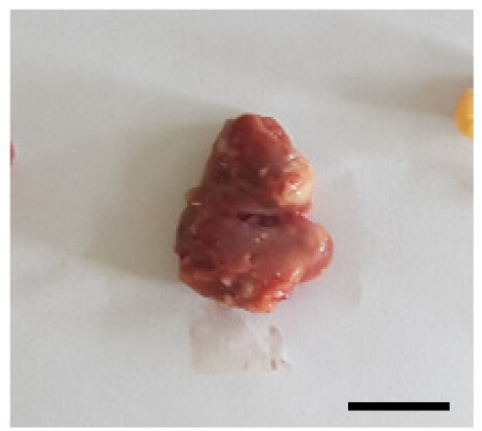

C

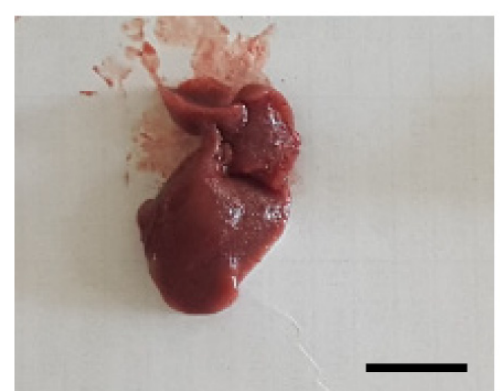

B

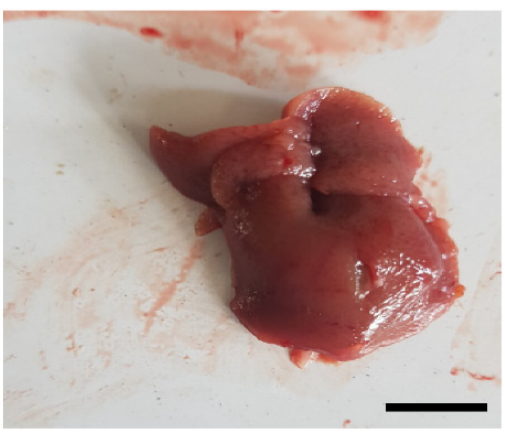

D

Figure 5. Photographs of liver recovered from the experimental animals. (A) Liver of untreated mice (NaCl); (B) liver section of group 2 (poly A.E); (C) liver section of group 3 (CCl4); (D) liver section of group 4 (poly A.E + CCl4). Scale bar: $10 \mathrm{~mm}$.

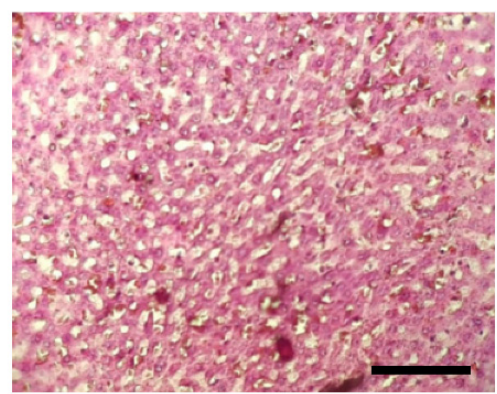

A

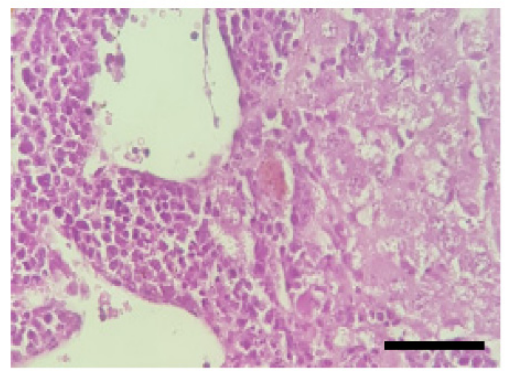

C

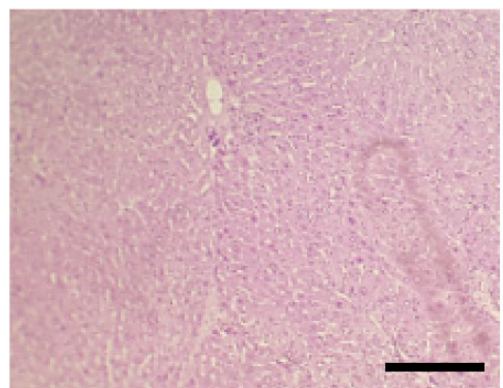

B

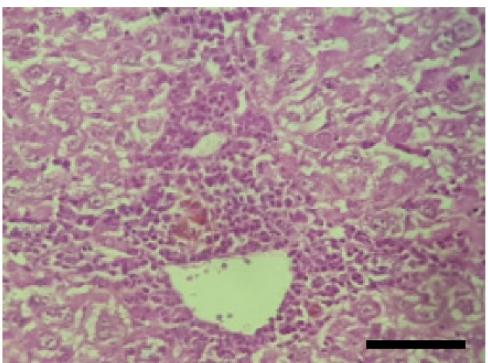

D

Figure 6. Microscopic photomicrographs of liver slices stained with HES (Hematosin and Eosin) $(\times 40)$. (A) Liver section of untreated mice (group 1) with normal liver parenchyma; (B) liver section of group 2 (poly A.E) with parenchyma; (C) liver section of group 3 (CCl4) with cavitation, degeneration, and necrosis; (D) liver section of group 4 (poly A.E + CCl4) with insignificant histological modifications. Scale bar: $10 \mathrm{~mm}(\times 40)$. 


\section{Discussion}

Liver disease is responsible for an estimated two million deaths per year worldwide. In low-income countries, it is the most neglected health issue $[16,17]$. The liver is a key organ involved in the regulation of diverse processes including metabolism, detoxification, and immune function, and therefore, it is the frequent target of chemical injury. The liver is the only visceral organ that possesses the ability to regenerate damaged tissue after either surgical removal or after chemical injury. However, multiple cases, such as hepatitis virus, long-term alcohol use, many different drugs, and xenobiotics including carbon tetrachloride may cause chronic liver damage in which regenerative ability becomes dysfunctional $[18,19]$.

Carbon tetrachloride is widely used as a key substance to investigate liver injury models in animals and dysfunction of hepatic cells which is associated with oxidative stress and free radicals [2]. The mechanisms of carbon tetrachloride-induced liver injury involve the accumulation of lipid peroxidation or covalent binding of carbon tetrachloride metabolites to cell constituents $[20,21]$.

The present work aimed to evaluate the potential hepatoprotective effect of polyphenols extracted from A. europaea against carbon tetrachloride-induced chronic liver injury in mice. The phytochemical study of A. europaea using high-performance liquid chromatography revealed the presence of interesting chemicals including ferulic acid, gallic acid, methyl gallate, rutin, and resorcinol (Figures 3 and 4; Table 1). Our results were partially in agreement with previous works reporting some similar compounds $[4,8]$.

The biochemical parameters AST and ALT are frequently used to indicate liver function after being exposed to chronic injuries. Liver damage stimulates the release of aminotransferases from damaged hepatocytes, which become higher in the blood circulatory system [22].

The treatment of mice with A. europaea polyphenols at a dose of $50 \mathrm{mg} / \mathrm{Kg}$ showed no histological nor biochemical alterations, and therefore, we can confirm its safety in animals (Figures 5 and 6; Table 2). In the plasma of mice treated with carbon tetrachloride alone (group 3), AST (U/L) and ALT (U/L) significantly increased when compared to the untreated group (Table 2). The serum activity of transaminases was also not significantly affected in the plasma recovered from the experimental group 4 (poly A.E + CCl4) when compared to both group 3 (CCl4 alone) and group $1(\mathrm{NaCl})$. Based on the results obtained, it is evident that the oral administration of A. europaea polyphenols at a dose of $50 \mathrm{mg} / \mathrm{Kg}$ maintained the activity of transaminases around a normal level in the mice treated with carbon tetrachloride during the whole period of dosing.

These data were also supported by histopathological analysis of liver recovered from the mice treated with carbon tetrachloride alone, where we noted serious histopathological modifications, unlike group $1(\mathrm{NaCl})$ and group 3 (poly A.E + CCl4) (Figures 5 and 6). These results were in agreement with those reported in the earlier literature, which showed that carbon tetrachloride induces severe histological liver injury [20].

The histopathological analysis of liver sections excised from group 2 treated with carbon tetrachloride alone showed the presence of various serious histopathological alterations including cavitations and necrosis as well as nuclear changes. These results are consistent with those found by Chang et al. (2011) in rats treated with carbon tetrachloride [14]. No significant histological modifications were noted for liver sections recovered from the mice treated with poly A.E+ $\mathrm{CCl} 4$ (group 3) when compared to group 2 (CCl4 alone). These data suggest that polyphenols of $A$. europaea may have an interesting role in protecting the liver from xenobiotics including carbon tetrachloride, and therefore, we can confirm that polyphenol-rich fractions from A. europaea protected the liver from being altered by carbon tetrachloride. Similar results have been obtained for Caralluma umbellate against acetaminophen-induced oxidative stress and liver damage in rats [23].

Various scientific research has revealed that polyphenol-based plants are potential sources of antioxidants that have numerous therapeutic effects including a hepatoprotective effect $[24,25]$. The protective effect of $A$. europaea polyphenols against carbon tetrachloride- 
induced liver injury may be related to the presence of gallic acid, rutin, and ferulic acid identified via HPLC analysis (Figure 3 and Table 1) since these compounds had some pharmacological activities, as reported in the previous literature, as follows: garlic inhibits lipid peroxidation, modulates the activity of antioxidant enzymes, and reduces liver lesions induced by CCl4 [26]; rutin reverses the alteration in expression of IL-6/STAT3 genes induced by carbon tetrachloride [2,27]; ferulic acid mitigates nuclear translocation of nuclear factor-kB (NF-kB) and decreases levels of inhibitors of NF-kB in cytosol increased by carbon tetrachloride [28,29].

\section{Conclusions}

This study sheds light on the potential beneficial hepatoprotective effect of A. europaea polyphenols against carbon tetrachloride-induced hepatic injury by maintaining the level of serum liver enzymes around normal values and inhibiting histological injuries. Further work on the mechanism of action by which A. europaea polyphenols exhibit a hepatoprotective effect has been planned for better understanding. Therefore, we can confirm that A. europaea extract is a promising source of hepatoprotective agents against toxic liver injury.

Author Contributions: F.E.-Z.A. and M.B.: writing original draft; M.S., S.B., and A.G.: formal analysis; R.U., E.E., and G.A.E.M.: revision and editing; D.B.: methodology and supervision. All authors have read and agreed to the published version of the manuscript.

Funding: This research was funded by King Saud University via the research supporting project number (RSP/2020/45). The research was also supported by European project Horizon 2020 MSCARISE-2016 734759-VAHVISTUS.

Institutional Review Board Statement: The institutional ethical committee of care and use of the laboratory animals at the Faculty of Sciences Dhar El Mehraz, Sidi Mohamed Ben Abdallah Fez University, Morocco, reviewed and approved the present study \# 04/2019/LBEAS.

Informed Consent Statement: Not applicable.

Data Availability Statement: The data used to support the findings of this study are available from the corresponding author upon request.

Acknowledgments: Authors are thankful to King Saud University for their financial support via the research supporting project number (RSP/2020/45). The authors are also grateful for the support of the European project Horizon 2020 MSCA-RISE-2016-734759-VAHVISTUS.

Conflicts of Interest: The authors declare no conflict of interest.

\section{Abbreviations}

A. europaea: Apteranthes europaea (Guss.) Murb. subsp. maroccana (Hook.f.) Plowes; CCl4: Carbon tetrachloride; i.p: intraperitoneally; o.p: Per Os; Poly A.E: Apteranthes europaea (Guss.) Murb.polyphenols.

\section{References}

1. Grant, D.M. Detoxification Pathways in the Liver. J. Inherit. Metab. Dis. 1991, 421-430. [CrossRef]

2. Hafez, M.M.; Al-Harbi, N.O.; Al-Hoshani, A.R.; Al-Hosaini, K.A.; Al Shrari, S.D.; Al Rejaie, S.S.; Sayed-Ahmed, M.M.; AlShabanah, O.A. Hepato-protective effect of rutin via IL-6/STAT3 pathway in CCl4-induced hepatotoxicity in rats. Biol. Res. 2015, 48, 1-10. [CrossRef]

3. Madrigal-Santillán, E.; Madrigal-Bujaidar, E.; Álvarez-González, I.; Sumaya-Martínez, M.T.; Gutiérrez-Salinas, J.; Bautista, M.; Morales-González, Á.; y González-Rubio, M.G.; Aguilar-Faisal, J.L.; Morales-González, J.A. Review of natural products with hepatoprotective effects. World J. Gastroenterol. 2014, 20, 14787-14804. [CrossRef]

4. Dra, L.A.; Sellami, S.; Rais, H.; Aziz, F.; Aghraz, A.; Bekkouche, K.; Markouk, M.; Larhsini, M. Antidiabetic potential of Caralluma europaea against alloxan-induced diabetes in mice. Saudi J. Biol. Sci. 2019, 26, 1171-1178. [CrossRef] [PubMed]

5. Bellakhdar, J.; Claisse, R.; Fleurentin, J.; Younos, C. Repertory of standard herbal drugs in the Moroccan pharmacopoea. J. Ethnopharmacol. 1991, 35, 123-143. [CrossRef] 
6. Dra, L.A.; Aghraz, A.; Boualy, B.; Oubaassine, S.; Barakate, M.; Markouk, M.; Larhsini, M. Chemical Characterization and In vitro Antimicrobial Activity of Caralluma europaea Essential Oil and Its Synergistic Potential with Conventional Antibiotics. J. Adv. Med. Pharm. Sci. 2018, 1-11. [CrossRef]

7. Issiki, Z.; Moundir, C.; Marnissi, F.; Seddik, N.; Benjelloun, N.; Zaid, Y.; Oudghiri, M. Toxicological Evaluation of the Aqueous Extract of Caralluma europaea and Its Immunomodulatory and Inflammatory Activities. Pharmacogn. Res. 2017, 9, 390-395. [CrossRef]

8. Bourhia, M.; Slighoua, M.; Ibnemoussa, S.; Bari, A.; Ullah, R.; Amaghnouje, A.; Di Cristo, F.; El Mzibri, M.; Calarco, A.; Benbacer, L.; et al. Phytochemical Study on Antioxidant and Antiproliferative Activities of Moroccan Caralluma europaea Extract and Its Bioactive Compound Classes. Evid.-Based Complement. Altern. Med. 2020, e8409718. [CrossRef]

9. Adnan, M.; Jan, S.; Mussarat, S.; Tariq, A.; Begum, S.; Afroz, A.; Shinwari, Z.K. A review on ethnobotany, phytochemistry and pharmacology of plant genus Caralluma R. Br. J. Pharm. Pharmacol. 2014, 66, 1351-1368. [CrossRef]

10. Bellakhdar, J. La Pharmacopée Marocaine Traditionnelle: Médecine Arabe Ancienne Et Savoirs Populaires-Saint-Etienne; Persée-Portail des revues scientifiques en SHS; Ibis Press: Saint-Etienne, France, 1997; Volume 35.

11. Dra, L.A.; Rodrigues, M.J.; Da Rosa Neng, N.; Nogueira, J.M.; Elamine, Y.; Aghraz, A.; Markouk, M.; Larhsini, M.; Custódio, L. Exploring Caralluma Europaea (Guss.) N.E.Br. as a Potential Source of Bioactive Molecules: In Vitro Antioxidant and Antidiabetic Properties, and Phenolic Profile of Crude Extracts and Fractions. Ind. Crops Prod. 2019. Available online: https: / / agris.fao.org/agris-search/search.do?recordID=US201900393756 (accessed on 1 October 2020).

12. Ho, C.-T.; Chen, Q.; Shi, H.; Zhang, K.-Q.; Rosen, R.T. Antioxidative effect of polyphenol extract prepared from various Chinese teas. Prev. Med. 1992, 21, 520-525. [CrossRef]

13. Seal, T. Quantitative HPLC analysis of phenolic acids, flavonoids and ascorbic acid in four different solvent extracts of two wild edible leaves, Sonchus arvensis and Oenanthe linearis of North-Eastern region in India. J. Appl. Pharm. Sci. 2016, 6, 157-166. [CrossRef]

14. Chang, J.B.; Wu, M.F.; Yang, Y.Y.; Leu, S.J.; Chen, Y.L.; Yu, C.S.; Yu, C.C.; Chang, S.J.; Lu, H.F.; Chung, J.G. Carbon tetrachlorideinduced hepatotoxicity and its amelioration by Agaricus blazei Murrill extract in a mouse model. In Vivo 2011, 25, 971-976. [PubMed]

15. Chebaibi, M.; Bousta, D.; Chbani, L.; Zoubi, Y.E.; Touiti, N.; Achour, S. Acute toxicity of plants mixture used in traditional treatment of edema and colic renal in Morocco. Sci. Afr. 2019, 6, e00152. [CrossRef]

16. Cainelli, F. Liver diseases in developing countries. World J. Hepatol. 2012, 4, 66-67. [CrossRef]

17. Asrani, S.K.; Devarbhavi, H.; Eaton, J.; Kamath, P.S. Burden of liver diseases in the world. J. Hepatol. 2019, 70, 151-171. [CrossRef]

18. Saha, P.; Talukdar, A.D.; Nath, R.; Sarker, S.D.; Nahar, L.; Sahu, J.; Choudhury, M.D. Role of Natural Phenolics in Hepatoprotection: A Mechanistic Review and Analysis of Regulatory Network of Associated Genes. Front. Pharmacol. 2019, 10. [CrossRef]

19. Österreicher, C.H.; Trauner, M. Xenobiotic-induced liver injury and fibrosis. Expert Opin. Drug Metab. Toxicol. 2012, 8, 571-580. [CrossRef]

20. Kim, H.Y.; Kim, J.K.; Choi, J.H.; Jung, J.Y.; Oh, W.Y.; Kim, D.C.; Lee, H.S.; Kim, Y.S.; Kang, S.S.; Lee, S.H.; et al. Hepatoprotective Effect of Pinoresinol on Carbon Tetrachloride-Induced Hepatic Damage in Mice. J. Pharmacol. Sci. 2010, 112, 105-112. [CrossRef] [PubMed]

21. Becker, E.; Messner, B.; Berndt, J. Two mechanisms of CCl4-induced fatty liver: Lipid peroxidation or covalent binding studied in cultured rat hepatocytes. Free Radic. Res. Commun. 1987, 3, 299-308. [CrossRef]

22. Lin, S.Y.; Xu, D.; Du, X.X.; Ran, C.L.; Xu, L.; Ren, S.J.; Tang, Z.T.; Yin, L.Z.; He, C.L.; Yuan, Z.X.; et al. Protective Effects of Salidroside against Carbon Tetrachloride (CCl4)-Induced Liver Injury by Initiating Mitochondria to Resist Oxidative Stress in Mice. Int. J. Mol. Sci. 2019, 20, 3187. [CrossRef]

23. Shanmugam, G.; Ayyavu, M.; Rao, D.M.; Devarajan, T.; Subramaniam, G. Hepatoprotective effect of Caralluma umbellate against acetaminophen induced oxidative stress and liver damage in rat. J. Pharm. Res. 2013, 6, 342-345. [CrossRef]

24. Nabavi, S.F.; Nabavi, S.M.; Habtemariam, S.; Moghaddam, A.H.; Sureda, A.; Jafari, M.; Latifi, A.M. Hepatoprotective effect of gallic acid isolated from Peltiphyllum peltatum against sodium fluoride-induced oxidative stress. Ind. Crops Prod. 2013, 44, 50-55. [CrossRef]

25. Khan, M.Z.; Shabbir, M.I.; Saqib, Z.; Gilani, S.A.; Jogezai, N.U.; Kiyani, M.M.; Malik, M.A. Investigation of polyphenol profile, antioxidant activity and hepatoprotective potential of Aconogonon alpinum (All.) Schur roots. Open Chem. 2020, 18, 516-536. [CrossRef]

26. Tung, Y.-T.; Wu, J.-H.; Huang, C.-C.; Peng, H.-C.; Chen, Y.-L.; Yang, S.-C.; Chang, S.-T. Protective effect of Acacia confusa bark extract and its active compound gallic acid against carbon tetrachloride-induced chronic liver injury in rats. Food Chem. Toxicol. 2009, 47, 1385-1392. [CrossRef] [PubMed]

27. Domitrovic, R.; Jakovac, H.; Marchesi, V.V.; Vladimir-Knežević, S.; Cvijanovic, O.; Tadić, Ž.; Romić, Ž.; Rahelić, D. Differential hepatoprotective mechanisms of rutin and quercetin in CCl4-intoxicated BALB/cN mice. Acta Pharmacol. Sin. 2012, 33, 1260-1270. [CrossRef]

28. Rukkumani, R.; Aruna, K.; Varma, P.S.; Menon, V.P. Hepatoprotective Role of Ferulic Acid: A Dose-Dependent Study. J. Med. Food 2004, 7, 456-461. [CrossRef]

29. Kim, H.-Y.; Park, J.; Lee, K.-H.; Lee, D.-U.; Kwak, J.-H.; Kim, Y.S.; Lee, S.-M. Ferulic acid protects against carbon tetrachlorideinduced liver injury in mice. Toxicology 2011, 282, 104-111. [CrossRef] 